\title{
A Mechanism for Mg Acceptor Activation in GaN by Low Energy Electron Beam Irradiation
}

\author{
M.R. Phillips", M. Merklein", T. Hardy ${ }^{*}$, T.J. Manning ${ }^{*}$ and M. Wintrebert-Fouquet ${ }^{* *}$ \\ * Microstructural Analysis Unit, University of Technology, Sydney, PO Box 123, Broadway \\ NSW 2007 Australia \\ ** BluGlass Limited, 74 Asquith Street, Silverwater, NSW 2128 Australia
}

P-type conductivity is achieved in GaN by incorporating $\mathrm{Mg}$ acceptors using a two-step process. First hydrogen is introduced during growth to form $\left(\mathrm{Mg}_{\mathrm{Ga}}-\mathrm{H}\right)^{\mathrm{O}}$ complexes to inhibit $\mathrm{Mg}$ acceptor self-compensation by native donors defects, such as nitrogen vacancies, $\mathrm{V}_{\mathrm{N}}$. Second after growth $\mathrm{Mg}$ acceptors are activated by dissociating the $\left(\mathrm{Mg}_{\mathrm{Ga}}-\mathrm{H}\right)^{\mathrm{O}} \rightarrow \mathrm{Mg}_{\mathrm{Ga}}{ }^{-}+\mathrm{H}^{+}$using rapid thermal annealing at $\sim 700^{\circ} \mathrm{C}$. Low energy electron beam irradiation (LEEBI) has also been used to activate acceptors in GaN:Mg using a conventional SEM, however, the exact mechanism for this effect is not completely understood.

LEEBI activation kinetics of $\mathrm{GaN}: \mathrm{Mg}$ have been studied as a function of temperature $\left(-190^{\circ} \mathrm{C}\right.$ to $\left.500^{\circ} \mathrm{C}\right)$, accelerating voltage $\left(\mathrm{E}_{\mathrm{O}}\right)$, beam current $\left(\mathrm{I}_{\mathrm{B}}\right)$ and irradiation time. The $\mathrm{Mg}$ acceptor concentration was monitored using scanning cathodoluminescence (CL) microscopy and spectroscopy. The experiments were conducted on $2 \mu \mathrm{m}$ thick $\mathrm{GaN}: \mathrm{Mg}$ layers on sapphire with a $[\mathrm{Mg}]=1 \times 10^{19} \mathrm{~cm}^{-3}$ and a hole concentration of $1 \times 10^{17} \mathrm{~cm}^{-3}$ as determined by Hall measurements. CL data were collected with a Gatan MonoCL3 system attached to a FEI Quanta 200 SEM.

Figure 1 and 2 show CL spectra before and after LEEBI irradiation at $25^{\circ} \mathrm{C}$ and $-190^{\circ} \mathrm{C}$ respectively. $\mathrm{LEEBI}$ treatment at $25^{\circ} \mathrm{C}$ increases the intensity of a $\mathrm{CL}$ emission peak at $3.27 \mathrm{eV}$ attributed to a free-to-bound $\left(\mathrm{e}, \mathrm{Mg}^{\circ}\right)$ transition, consistent with the creation of isolated $\mathrm{Mg}^{\circ}$ acceptors following dissociation of $\left(\mathrm{Mg}_{\mathrm{Ga}} \mathrm{H}\right)^{\mathrm{O}}$ complexes [1]. At $-190^{\circ} \mathrm{C}$ the $3.28 \mathrm{eV}$ ascribed to a donor-acceptor pair (DAP) transition involving a $\mathrm{C}_{\mathrm{N}}$ acceptor is quenched by the LEEBI process leaving a broad peak due to a $\mathrm{Mg}$ related DAP centred at $\sim 3.15 \mathrm{eV}$ [2]. The rate of change of these CL bands was found to follow first order kinetics, scale directly with the electron beam injection fluence (Fig. 3) and decrease with increasing temperature up to $\sim 260^{\circ} \mathrm{C}$ (Fig. 4).

First order kinetics are characteristic of bulk charge trapping. The density of trapped charge, $\mathrm{Q}(\mathrm{t}) \mathrm{cm}^{-3}$, can be expressed as $\mathrm{Q}(\mathrm{t})=\mathrm{N}_{\mathrm{t}}[1-\exp (-\mathrm{t} / \tau)]$, where $\tau=\left(v_{\mathrm{th}} \sigma \mathrm{n}_{\mathrm{e}}\right)^{-1}, v_{\text {th }}$ is the thermal velocity of electrons, $\sigma$ is the charge capture cross-section, $\mathrm{N}_{\mathrm{t}}$ is the density of charge traps and $\mathrm{n}_{\mathrm{e}}$ is the density of electrons. White the charge trapping rate can be written as $d Q(t) / d t \propto I_{B} R_{e} N_{t} \sigma$, where $R_{e}$ is the electron range [3]. Due to the competitive nature of the CL recombination process, as charge traps fill these pathways close, increasing recombination through the $\left(\mathrm{Mg}_{\mathrm{Ga}}-\mathrm{H}\right)^{\mathrm{O}}$ channel. These centres dissociate because the recombination energy $(\sim 3.4 \mathrm{eV})$ is greater than the $\mathrm{Mg}-\mathrm{H}$ binding energy $(\sim 1.6 \mathrm{eV})$. Quenching of the $3.28 \mathrm{eV}$ DAP 
band at $-190^{\circ} \mathrm{C}$ occurs because the liberated $\mathrm{H}$ from the $\left(\mathrm{Mg}_{\mathrm{Ga}}-\mathrm{H}\right)^{\mathrm{O}}$ defects binds to the $\mathrm{C}_{\mathrm{N}}$ acceptors forming stable $\left(\mathrm{C}_{\mathrm{N}^{-}} \mathrm{H}\right)$ complexes [3]. The decrease in the LEEBI activation rate from $-190^{\circ} \mathrm{C}$ to $\sim 260^{\circ} \mathrm{C}$ is consistent with the proposed model as the charge traps depopulate $\propto \exp (-$ $\mathrm{E}_{\mathrm{t}} / \mathrm{k}_{\mathrm{b}} \mathrm{T}$ ) with increasing $\mathrm{T}$, where $\mathrm{E}_{\mathrm{t}}$ is the trap depth energy. Above $\sim 260^{\circ} \mathrm{C}$ thermal dissociation of the $\left(\mathrm{Mg}_{\mathrm{Ga}}-\mathrm{H}\right)^{\mathrm{O}}$ dominates the activation process. The results indicate that the LEEBI Mg acceptor activation rate in $\mathrm{GaN}$ is mediated by bulk charge trapping kinetics.

\section{References}

[1] O. Gelhausen, M.R. Phillips, E.M. Goldys, T.Paskova, B. Monemar, M. Strassburg and A. Hoffmann, Physical Review B, 69 (2004) 12510

[2] T.A.G. Eberlain, R. Jones, S. Oberg, P.R. Bridden, Applied Physics Letters 91 (2007) 132105

[3] J. Cazaux, Journal of Applied Physics, 85 (1999) 1137

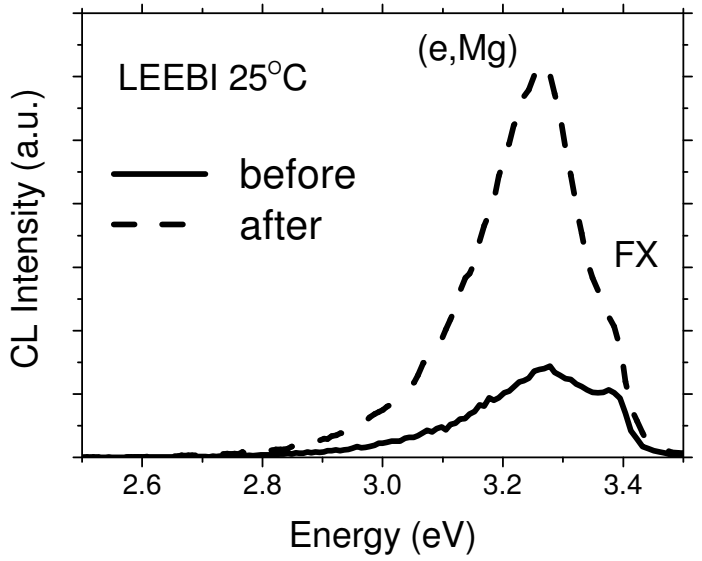

Figure $1 \mathrm{LEEBI}$ at $25^{\circ} \mathrm{C} 60 \mathrm{~s} 15 \mathrm{kV} 7.1 \mathrm{nA} 15 \mathrm{x} 13 \mu \mathrm{m}$ Spectra $15 \mathrm{kV} 7.1 \mathrm{nA} 75$ x $65 \mu \mathrm{m}$

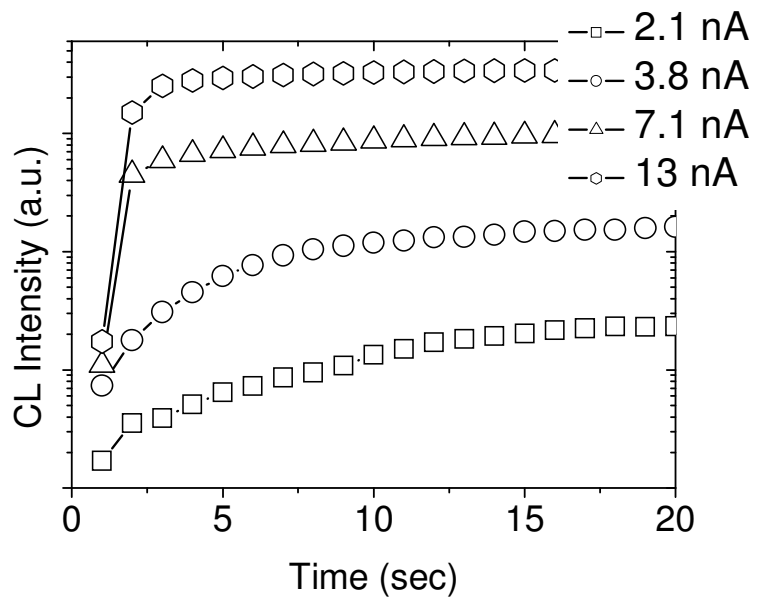

Figure 3 LEEBI $\mathrm{I}_{\mathrm{B}}$ dependence at $25^{\circ} \mathrm{C} 15 \mathrm{kV} 7.1 \mathrm{nA}$ $15 \times 13 \mu \mathrm{m}$

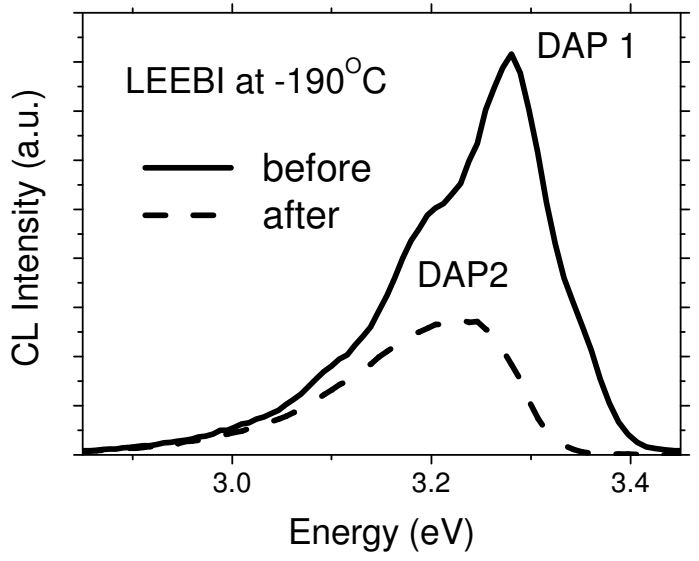

Figure $2 \mathrm{LEEBI}$ at $-190^{\circ} \mathrm{C} 60 \mathrm{~s} 15 \mathrm{kV} 7.1 \mathrm{nA}$ 15 x $13 \mu \mathrm{m}$ Spectra $15 \mathrm{kV} 7.1 \mathrm{nA} 75$ x $65 \mu \mathrm{m}$

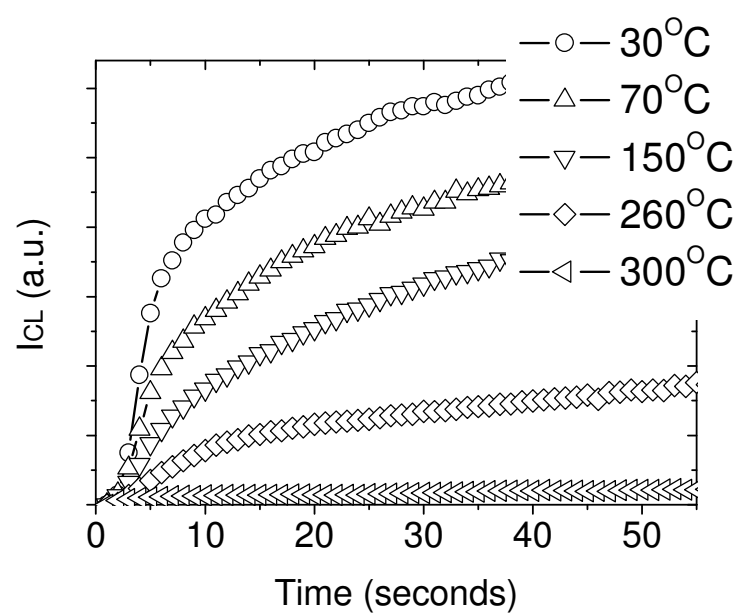

Figure 4 LEEBI temperature dependence $25^{\circ} \mathrm{C}$ $15 \mathrm{kV} 7.1 \mathrm{nA} 15$ x $13 \mu \mathrm{m}$ 